\section{Was Hitler a Christian?}

SIR: Philip Timms (Journal, April 1990, 156, 590) finds it hard to come to terms with the Christianity professed by Hitler, Mussolini, Stalin, Franco and Rudolf Hoess, Commandant of Auschwitz. He is not alone.

In 1960 Professor Jules Isaac asked "Did the Nazis spring from nothing or from the bosom of a Christian people? ... Rudolph Hoess ... came from a pious Catholic family and had considered taking Holy Orders." Stalin, on the other hand, did go to a theological seminary in order to become a priest of the Russian Orthodox Church. He was, unfortunately, expelled for being found in possession of political pamphlets. Furthermore, Joachim Kah (1971) stated "Adolf Hitler ... was a Catholic Christian who never left the Church and was never excommunicated. His book, Mein Kampf, was never placed on the index of prohibited books which, until recently, included all books and articles that were contradictory to Catholic teaching in matters of morals and faith. Apparently, Hitler's political aims did not contradict Catholic moral teaching in any way."

Would Dr Timms now be prepared to reconsider his ultimate sentence? The use of the word 'Christian' conforms with the dictionary definition he gives. It is not 'inaccurate' or 'misleading'. If it is "potentially offensive to both Christians and non-Christians", then I am sorry. The millions who were murdered in my childhood in Christian Europe deserve the truth be told.

\section{Cate Garden \\ Petersfield \\ Hampshire GU32 3AG}

\section{References}

IsAAC, J. (1960) The Christian Roots of Antisemitism. London: Council of Christians and Jews.

KAHL, J. (1971) The Misery of Christianity, p. 60. London: Penguin Books.

\section{More on double-blindness}

SIR: Drs Oxtoby et al (Journal, November 1989, 155, $700-701$ ) recently pointed out that the blindness of a double-blind trial may be broken and invalidate the result of the trial. They suggest measuring blindness and correcting for any breaks in the blindness.

We constructed a method to test if the blindness of the trial was broken, and if so, whether such a break invalidated the results of the study (Hughes \&
Krahn, 1985). Interestingly, we found on four occasions that the blindness of a trial was broken but this did not invalidate the results (Hughes et al, 1984, 1985, 1989, 1990).

I would like to make some comments based on our experience in this area. First, in some studies the chance of receiving an active drug or placebo is not 50:50 (e.g. studies of two active doses and a placebo). In such studies that give full informed consent, patients are usually acutely aware of their increased chances of receiving an active drug and a high proportion will believe they have received this (e.g., $87 \%$ in one study; Hughes et al, 1990).

Second, it is very important to distinguish between breaks due to appearance, side-effects, taste, or smell of medications and those due to presence or absence of therapeutic efficacy (see Hughes et al, 1986). We found that if a psychoactive drug has a large effect, breaks in blindness due to efficacy are very likely (Hughes et al, 1984, 1989). Thus, in a way, breaks in the blindness can be a sign of therapeutic potential.

Third, although the experimenter may make a distinction between breaks due to side-effects etc. and those due to efficacy, our experience has been that patients often have difficulty doing so.

Fourth, if an assessment of blindness is taken at the end of a trial, it is impossible to say whether the break in blindness led to a change in efficacy or whether a change in efficacy led to a break in blindness (Hughes \& Krahn, 1985).

Finally, it is tempting to assess blindness repeatedly throughout a trial to see whether breaks in blindness preceded or succeeded changes in ratings of efficacy or side-effects. However, the risk of this procedure is that it encourages subjects to try to break the blindness (Hughes \& Krahn, 1985).

In summary, my major point is that one should not automatically conclude that a break in the blindness of a study is causally related to the discovery of sideeffects and invalidates the study.

Psychology and Family Practice

JOHN R. HUGHES

Department of Psychiatry

University of Vermont

Burlington VT, USA 05401-Z

\section{Roferences}

HuGres, J. R. \& KRAHN, D. (1985) Blindness and the validity of double-blind drug trials. Journal of Clinical Psychopharmacology, 5, 138-142.

- Hatsukama, D. K., Pickens, R. W. et al (1984) Efiect of nicotine on the tobacco withdrawal syndrome. Psychopharmacology. 83, 82-87.

—, Hatsukama, D. K. \& Sxoog, K. (1986) Physical dependence on nicotine gum: a placebo-substitution trial. Journal of the American Medical Association, 255, 3277-3279. 
Hughes, J.R., Gust, S. W., KeENAN, R. M. et al (1989) Nicotine vs placebo gum in general practice. Journal of the American Medical Association, 261, 1300-1305.

,,--- et al (1990) Effect of dose on nicotine's reinforcing, withdrawat-suppression and self-reported efiects. Journal of Pharmacology and Experimental Therapeutics (in press).

\section{Phototherapy, winter depression and ocular pressure}

SIR: There is evidence to suggest that in depression, homeostatic regulatory mechanisms are more erratic and/or less responsive to incoming stimuli (Siever \& Davis, 1985). We have recently proposed that among many putative systems, ocular pressure dynamics may also be poorly regulated in at least a subgroup of seasonally depressed patients. It has been thus reported that patients with seasonal affective disorder (SAD) may, in the late afternoon, have significantly lower intraocular pressure (IOP) when compared with age- and sex-matched controls (Stojek \& Bilikiewicz, 1988). We have also shown (Stojek et al, 1990) that seasonally depressed women have a substantial reduction in rate of secretion of the aqueous fluid.

We now wish to report the results from tonometric and tonographic examinations performed between 9.00 a.m. and 10.00 a.m. in ten SAD women, before and after three days' treatment with bright ( 2500 lux) light for two hours twice a day (6.00 to 8.00, a.m. and p.m.). All the patients met DSM-III criteria for a major depression that developed during the fall or winter and remitted the following spring, for at least three consecutive years. Patients were entered into the study if they had, (1) a score of 16 or more on the 21-item Hamilton Rating Scale for Depression (HRSD), and (2) if their current history of winter depression was characterised by morning oversleeping. They all gave written informed consent to participate in the study. Studies were made from January through to December during the luteal phase of the menstrual cycle, to avoid a possible variation in IOP within this cycle. The ocular examinations were normal, and most of the eyes were emmetropic. Applanation tonometry with a plunger load of $5.5 \mathrm{~g}$ was performed on both eyes and the results were then averaged. The tonographic study was made on the right eye only. Facility of outflow (C) and rate of flow (F) were calculated according to Becker \& Schaffer (1961), and the episceral venous pressure of $8 \mathrm{mmHg}$ was used for these calculations. Data were analysed by paired $t$-test.

Bright light had a marked antidepressant effect (HDRS decreased from 23.6 to 5.9, $P<0.01$ ), and this was accompanied by a vivid reduction of the morning hypersomnia. The tonometric and tonographic studies revealed that after phototherapy, the mean (s.d.) IOP increased from 12.3(1.7) to $14.2(1.1) \mathrm{mmHg}(P<0.01)$. Likewise, the mean (s.d.) $\mathrm{F}$ before and after treatment increased from $1.18(0.47)$ to $3.2(0.98) \mathrm{c} \mathrm{mm} / \mathrm{min}$, respectively $(P<0.01)$, and the $C$ value increased from $0.21(0.04)$ to $0.34(0.11) \mathrm{c} \mathrm{mm} / \mathrm{min}$, respectively $(P<0.01)$. Both IOP and $F$ values increased most significantly in those two patients who were still given a moderate dose of tricyclic antidepressants.

While caution is warranted in interpreting data from only 10 patients, these findings, if considered in conjunction with previous work, suggest that phototherapy may improve the winter depression and attenuate the morning oversleeping parallel with increases in the amplitude of ocular pressure dynamics, and that the important factor might be the relative rates at which production of fluid and its elimination take place. Thus, an increased blood supply to the epithelial cells might be a critical factor in determining the availability of fluid and solutes into the eye during the light treatment. Some authors have theorised that increased IOP results from vascular changes in the eye that are irritated by the prolonged darkness and cold temperature of winter (Blumenthal et al, 1970). Since light per se increases the flow of clear fluid in normal eyes, but could sometimes have the opposite effect (Saeteren, 1960), it would thus be interesting to know whether the latter possibility might account for a wellknown phenomenon of supersensitivity to light in, at least, the SAD patients.

ANDRZej Stojek BOZENA KASPRZAK

Department of Psychiatry ADAM BILIKIEWICZ

School of Medicine in Gdansk

80-282 Gdansk-Wrzeszcz

1 Srebriniki St, Poland

\section{References}

BeCKER, B. \& SCHAFrer, R. (1961) Diagnosis and Therapy of Glaucoma. St Louis: Mosby Co.

Blumenthal, M., Blumenthal, R., Peritz, E. el al (1970) Seasonal variation in intraocular pressure. American Journal of Ophthalmology, 69, 608-610.

SAETEREN, T. (1960) Scleral rigidity in normal human eyes. Acta Ophtalmologica, 38, 303-311.

SteVER, L. J. \& DAvis, K. L. (1985) Overview: toward a dysregulation hypothesis of depression. American Journal of Psychiatry, 142, 1017-1031

Storex, A. \& Biunkiewicz, A. (1988) Bright artificial light lowers intraocular pressure and plasma sodium concentration less in depressed patients than healthy controls. Plinensky Lekarsky Sbornik, 56, 157-160.

Stojex, A., Kasprzak, B. \& Bulniewicz, A. (1990) Changes in ocular humor dynamics in SAD patients after phototherapy. Paper accepted for presentation at the 18th European Conference on Psychosomatic Research, 13-17 August 1990, Helsinki, Finland. 